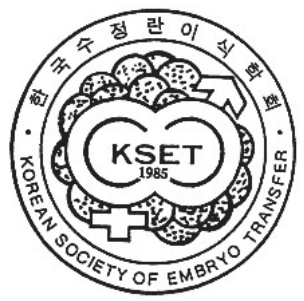

\title{
Reversible Effects of Exogenous GM3 on Meiotic Maturation and Cumulus Cells Expansion of Porcine Cumulus-oocyte Complexes
}

Jin-Woo Kim, Hyo-Jin Park, Jae-Min Jung, Seul-Gi Yang, Min-Ji Kim, In-Su Kim, Ho-Geun Jegal and Deog-Bon $\mathrm{Koo}^{\dagger}$

Department of Biotechnology, College of Engineering, Daegu University, 201 Daegudae-ro, Jillyang, Gyeongsan, Gyeongbuk 38453, Republic of Korea

\section{Abstract}

Ganglioside GM3 is known as an inhibition factor of cell differentiation and proliferation via inhibition of epidermal growth factor receptor (EGFR) phosphorylation. Our previous study showed that the exogenous ganglioside GM3 reduced the meiotic maturation of porcine oocytes and induced apoptosis at $44 \mathrm{~h}$ of in vitro maturation (IVM). However, the role of ganglioside GM3 in the relationship between EGFR signaling and apoptosis during porcine oocyte maturation has not yet been studied. First, porcine cumulus-oocyte complexes (COCs) were cultured in the NCSU-23 medium with exogenous ganglioside GM3 according to maturation periods (non-treated, only IVM I: 0 - 22 h, only IVM II: 22 - $44 \mathrm{~h}$ and IVM I \& II: 0 - 44 h) We confirmed that the proportion of germinal vesicle breakdown (GVBD) increased significantly in the IVM I treated group than in the control group. We also confirmed that the meiotic maturation until M II stage and polar body formation decreased significantly in the only IVM I treated group. Cumulus cell expansion and mRNA levels of the expansion-related factors (HAS2, TNFAIP6 and PTX3) decreased significantly in the IVM I treated group than in the control group. Protein levels of EGFR, p-EGFR, ERK1/2, and p-ERK1/2 decreased significantly in the GM3-treated groups, during the IVM I period. In addition, cellular apoptosis, determined using TUNEL assay, and protein levels of Cleaved caspase 3, were increased significantly in the GM3-treated COCs during the IVM I period. Based on these results, ganglioside GM3 exposure of porcine COCs during the IVM I period reduced meiotic maturation and cumulus cell expansion via inhibition of EGFR activity in pigs.

Received : 3 December 2018

Revised : 13 December 2018

Accepted : 19 December 2018

Key Words : Ganglioside GM3, Oocytes maturation, EGFR, Apoptosis, Pig

† Correspondence: Deog-Bon Koo (ORCID: 0000-0001-7825-9598)

Tel: +82-53-850-6557, Fax: +82-53-850-6559

E-mail address: dbkoo@daegu.ac.kr 


\section{INTRODUCTION}

Gangliosides, which are glycosphingolipids containing one or more sialic acid residues, exist in the plasma membrane of most mammalian cells (Julien, et al. 2013;Kim, et al. 2016). Gangliosides play a role in the regulation of various biological processes, such as differentiation, apoptosis, and signaling in animal cells (Huang, et al. 2013; Li, et al. 2015;Wang, et al. 2003). Gangliosides regulate the activity of tyrosine kinase receptors, such as epidermal growth factor receptor (EGFR), platelet-derived growth factor receptor (PDGFR), and fibroblast growth factor receptor (FGFR) in neuron and cancer cells (Julien, et al. 2013). Recent studies investigated the relevance of the relationship between gangliosides and early embryonic development in mice and pigs ( $\mathrm{Ju}$, et al. 2005; Kim, et al. 2016; Park, et al. 2017).

In vitro maturation (IVM) of oocytes is an important step for in vitro production (IVP) of embryos and blastocyst in pigs. During IVM progression, the relationship between oocytes and cumulus cells in cumulus-oocyte complexes (COCs) arranges the transfer of various nutrients and regulates receptor-related signaling, secretion functions, and gap junction signaling (Liu, et al. 2015). In addition, the activity of EGFR-mediated ERK1/2 induces cumulus expansion through the activation of cumulus cell expansionrelated factors, such as HAS2, TNFAIP6, and PTX3 during IVM of porcine oocytes (Meinecke and Krischek 2003;Sen and Caiazza 2013; Su, et al. 2003). In this process, EGFR-derived ERK1/2 signaling is known to play an important role in the cumulus cell expansion and meiotic maturation in oocytes of mammals, including mouse, human, porcine, and cattle oocytes (De La Fuente, et al. 1999;Goud, et al. 1998;Illera, et al. 1998;Rieger, et al. 1998)

Among the gangliosides, GM3 as a common precursor has the simplest structure and is the first product of the gangliosides synthesis process (Yoshikawa, et al. 2015). Ganglioside GM3 is well-known for the inhibition of EGFR-, FGFR-, and PDGFRrelated signal pathways in neuron cells (Julien, et al. 2013). In the reproductive system, ganglioside GM3 is expressed in Sertoli cells, sperm, developmental follicle, zygote, and developmental embryos in mice (Kwak, et al. 2011). Also, ganglioside GM3 expressions increased in the apoptosis-induced embryos in pigs and mice (Chae, et al. 2015; Ju, et al. 2005). Moreover, according to our previous study, exogenous ganglioside GM3 induces cellular apoptosis by blocking cell proliferation by reducing $\mathrm{PI} 3 \mathrm{~K} / \mathrm{AKT}$ signaling in porcine COCs during IVM (Park, et al. 2017). However, the effects of ganglioside GM3 in the relation of EGFR activity on meiotic maturation, polar body formation, and cumulus cells expansion in porcine COCs during IVM periods (metaphase I; $22 \mathrm{~h}$ and metaphase II; $44 \mathrm{~h}$ ) have not been reported.

Therefore, the aim of the present study was to investigate the changes in the meiotic maturation, cumulus cell expansion, and cumulus expansion factors via the EGFR-mediated ERK1/2 signaling activity according to ganglioside GM3 treatment periods (non-treated, only IVM I: 0 - 22 h, only IVM II: 22 - $44 \mathrm{~h}$ and IVM I \& IVM II: 0 - $44 \mathrm{~h}$ ) in porcine COCs (Graphical hypothesis, Figure 1).

\section{MATERIALS AND METHODS}

\section{Chemicals}

Unless otherwise stated, all chemicals used in this study were purchased from Sigma Chemical Co. (St. Louis, MO, USA).

\section{In vitro maturation (IVM)}

Porcine ovaries were obtained from the local slaughterhouse and carried to laboratory using $30-35^{\circ} \mathrm{C}, 0.9 \%$ saline added with $75 \mu \mathrm{g} / \mathrm{ml}$ potassium penicillin G. Follicular fluid was aspirated between $3-6 \mathrm{~mm}$ follicles using $10 \mathrm{ml}$ syringe with 18 gauge needle. After, immature cumulus-oocyte complexes (COCs) surrounded by cumulus cells were selected using mouth pipettes under the microscope. And then, COCs washed three times in tyrode's lactate-4-(2-hydroxyethyl)-1-piperazine-ethanesulfonic acid (TLHEPES) medium. Selected COCs were matured in 4-well multidish (Nunc, Roskilde, Denmark) with $500 \mu \mathrm{l}$ IVM I medium at $38.5^{\circ} \mathrm{C}, 5 \% \mathrm{CO}_{2}$ in air. The IVM medium was Carolina State University (NCSU) 23 medium with $0.57 \mathrm{mM}$ cystein, 10\% follicular fluid, $10 \mathrm{ng} / \mathrm{ml}$ epidermal growth factor (EGF), $10 \mathrm{ng} / \mathrm{ml}$ $\beta$-mercaptoethanol, $10 \mathrm{IU} / \mathrm{ml}$ pregnant mare serum gonadotropin (PMSG) and $10 \mathrm{IU} / \mathrm{ml}$ human chorionic gonadotropin (hCG). After $22 \mathrm{~h}$, COCs were washed three times with IVM II medium without PMSG and hCG and then cultured in IVM II medium for $22 \mathrm{~h}$ at $38.5^{\circ} \mathrm{C}, 5 \% \mathrm{CO}_{2}$ in air. Our previous study confirmed that meiotic maturation and cumulus cells expansion of porcine COCs was reduced in $10 \mu \mathrm{M}$ GM3 during IVM (Park, et al. 2017). Therefore, all experiments were performed using $10 \mu \mathrm{M}$ GM3. During the maturation periods, ganglioside GM3 was added to the maturation medium according to three periods of IVM such as IVM I (0 - 22 h), IVM II (22 - 44 h), IVM I \& IVM II $(0-44 \mathrm{~h})$. 

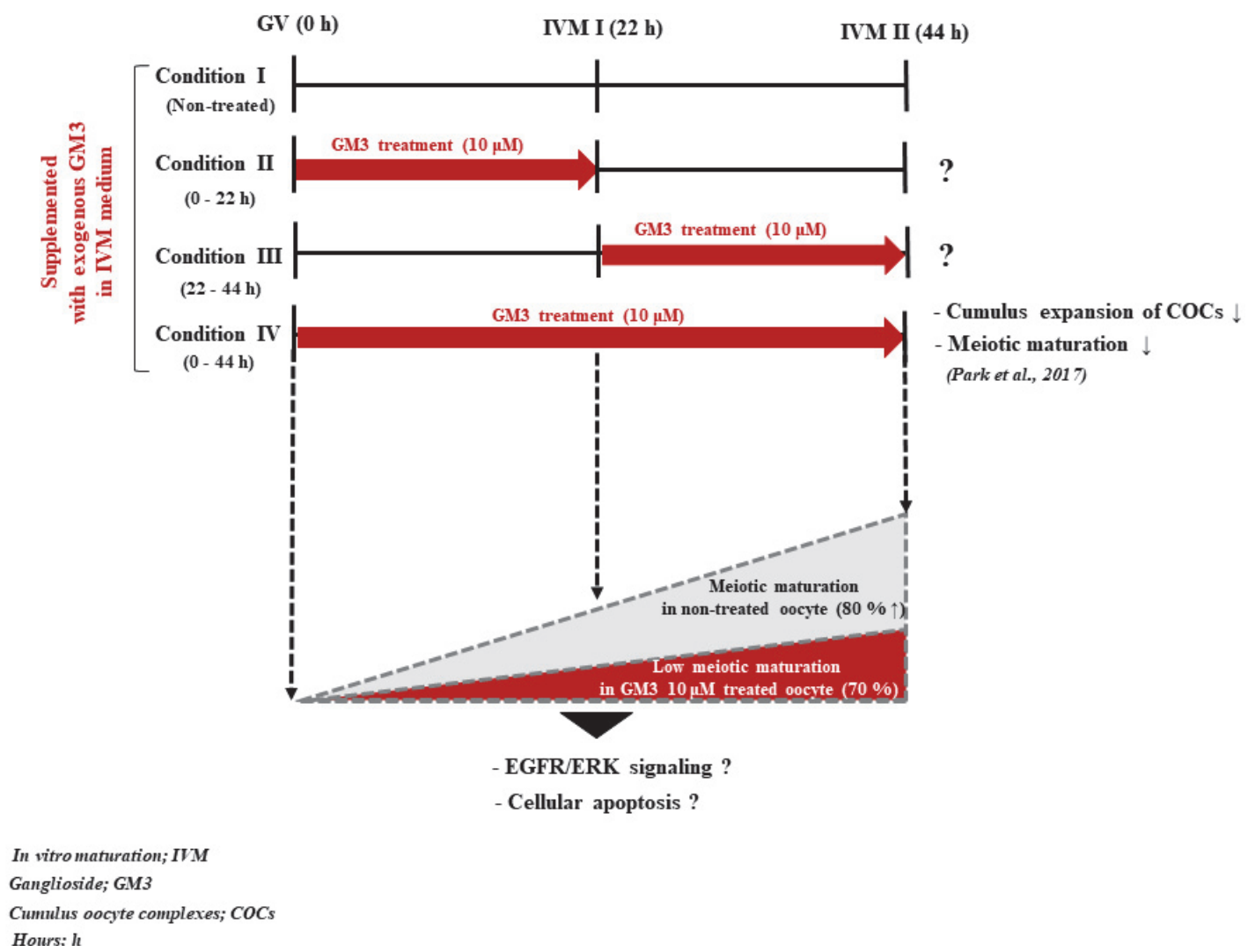

Figure 1. Schematics of the hypothesis and design for the effects of exogenous ganglioside GM3 on oocyte maturation and cumulus cell expansion in porcine COCs during $22 \mathrm{~h}$ and/or $44 \mathrm{~h}$ of IVM. We were divided into four groups of the exogenous ganglioside GM3; non-treated, IVM I (0 - 22 h), IVM II (22 - 44 h) and IVM I \& IVM II (0 - 44 h). After 44 h of IVM, we investigated that the changes in meiotic maturation, cumulus cells expansion and polar body production via EGFR-mediated ERK1/2 signaling in maturated COCs. Moreover, cellular apoptosis and Cleaved caspase 3 as apoptotic factor by GM3 treatment were observed using a TUNEL assay and Western blot analysis in matured COCs during IVM.

\section{Assessment of meiotic maturation and polar body extrusion}

At the end of IVM experiment, a representative sample was denuded by gently pipetting in $0.1 \%$ hyaluronidase (w:v) and then washing in PBS containing $0.1 \%$ polyvinyl alcohol (PVA, w:v). Then checking for extrusion of first polar body. Next, each sample were mounted on microscope slide. The samples were then fixed for 2 - 3 days in acetic acid:ethanol (1:3, v:v) solution and stained with $0.1 \%$ acetic orcein (v:v) solution for $5 \mathrm{~min}$. The samples were de-stained in glycerol:acetic acid:water (1:1:3, v:v:v) solution, after which the meiotic stage was evaluated microscopically (Leica, Solms, Germany).

\section{Assessment of cumulus cells expansion}

We evaluated the cumulus cells expansion under a optical microscope (Leica, Solms, Germany) after $44 \mathrm{~h}$ maturation. Assessment of cumulus cells expansion was performed as described by Mlynarcikova et al (Mlynarcikova, et al. 2009).
The degree of cumulus cells expansion was measured according to a subjective scoring system from 0 to +4 . No expansion (0), separation of only the outermost layer of cumulus cells $(+1)$, further expansion involving the outer half of the cumulus cells $(+2)$, further expansion up to, but not including, the corona radiate $(+3)$ and complete expansion including the corona radiated cells $(+4)$. Expanded COCs rated as +2 or higher were included in assessment.

\section{RT-PCR}

Total RNA was isolated from maturated COCs using Tri-zol reagent (Invitrogen, Carlsbad, CA) and quantified using nano Q. Extracted RNA from each sample were synthesized to cDNA using the AccuPower ${ }^{\circledR}$ CycleScript RT PreMix (Bioneer Inc., Daejeon, Korea) according to the manufacturer's instructions. RT-PCR analysis was performed on a AccuPower ${ }^{\circledR}$ PCR PreMix in a 20 $\mu \mathrm{l}$ reaction volume containing $1 \mu \mathrm{l}$ cDNA, $17 \mu \mathrm{l}$ distilled water, 
Table 1. Primer sequencing used for RT-RCR

\begin{tabular}{|c|c|c|c|c|c|}
\hline Gene & Genebank accession & primer & Sequence & $\operatorname{Tm}\left({ }^{\circ} \mathrm{C}\right)$ & $\begin{array}{l}\text { Product size } \\
\text { (base pairs) }\end{array}$ \\
\hline$H A S 2$ & NM_214053.1 & $\begin{array}{l}\text { Forward } \\
\text { Reverse }\end{array}$ & $\begin{array}{l}\text { TGGCTGTACAATGCGATGTG } \\
\text { GGTGAAAATCACACCACCCA }\end{array}$ & 55 & 402 \\
\hline$P T X 3$ & NM_001244783.1 & $\begin{array}{l}\text { Forward } \\
\text { Reverse }\end{array}$ & $\begin{array}{l}\text { TCAGTGCCTGCATTTGGGTC } \\
\text { CTACATGCCCTTGTTCAGAA }\end{array}$ & 58 & 225 \\
\hline TNFAIP6 & NM_001159607.1 & $\begin{array}{l}\text { Forward } \\
\text { Reverse }\end{array}$ & $\begin{array}{l}\text { TCTTCCTGTGGGAAGAGGCT } \\
\text { TCGCTTCTGTTCAGACGGAC }\end{array}$ & 55 & 337 \\
\hline$G A P D H$ & NM_001206359.1 & $\begin{array}{l}\text { Forward } \\
\text { Reverse }\end{array}$ & $\begin{array}{l}\text { GAAGGTCGGAGTGAACGGAT } \\
\text { CATGGACCGTGGTCATGAGT }\end{array}$ & 55 & 527 \\
\hline
\end{tabular}

and $10 \mathrm{pmol}$ each of forward and reverse primers (Table 1). The conditions for PCR were performed as follows: $95^{\circ} \mathrm{C}$ for $5 \mathrm{~min}$, and 25 - 30 cycle of denaturation at $95^{\circ} \mathrm{C}$ for $30 \mathrm{sec}$, annealing at 55 and $58^{\circ} \mathrm{C}$ for $30 \mathrm{sec}$, extension at $72^{\circ} \mathrm{C}$ for $30 \mathrm{sec}$, and $72^{\circ} \mathrm{C}$ for $5 \mathrm{~min}$. The products performed electrophoresis using $2 \%$ agarose gel and detected UV light.

\section{Western blot analysis}

COCs (20-25 per group) were placed into $2 \mu 1$ of $0.1 \%$ PVA-PBS and were added to $16 \mathrm{ul}$ PRO-PREP protein lysis buffer (iNtRON, Daejeon, Korea) and $4 \mu \mathrm{l}$ of $5 \mathrm{x}$ laemmli buffer. Protein samples was denatured at $100^{\circ} \mathrm{C}$ for $10 \mathrm{~min}$ and then separated on a $10-12 \%$ polyacrylamide gel by sodium dodecyl sulfate-polyacrylamide gel electrophoresis (SDS-PAGE; Hoefer, Holliston, MA, USA) for $3 \mathrm{~h}-3 \mathrm{~h} 30 \mathrm{~min}$ at $15 \mathrm{~mA}$, and transferred to a nitrocellulose membrane for $2 \mathrm{~h}$ at $400 \mathrm{~mA}$. The membrane was blocked with $5 \%$ skim milk or $5 \%$ BSA in Tris-buffered saline containing $1 \%$ Tween 20 (TBST) for overnight at $4^{\circ} \mathrm{C}$. The membrane was incubated with the appropriate primary antibody; anti-ST3GAL5 (ab65541, Abcam), anti-EGFR (sc-03, Santa Cruz), anti-phospho-EGFR (sc-12351, Santa Cruz), anti-ERK1/2 (\#9102, Cell Signaling), anti-phospho-ERK1/2 (\#9101, Cell Signaling), anti-Cleaved caspase 3 (\#9664, Cell Signaling) and anti- $\beta$-actin (sc-47778, Santa Cruz). Membranes were washed using TBST buffer and then incubated with a secondary antibody-HREconjugated anti- mouse/rabbit/goat IgG for $2 \mathrm{~h}$ room temperature. And then, the membranes were washed with TBST buffer. The signals were detected using the ECL kit. Band intensities were quantified with Image J software (NIH, MD, USA). All experiments were performed three times.

\section{TUNEL assay}

Apoptotic cumulus cells were detected using an In Situ Cell Death Detection Kit (Roche Diagnostics GmbH, Mannheim, Germany) according to the manufacturer's instructions. The COCs from IVM II were washed with $0.1 \%$ PVA in PBS and then fixed in $4 \%$ PFA in PBS for $1 \mathrm{~h}$ at room temperature. Next, COCs were permeablized using $0.1 \%$ (v:v) Triton X-100 for $30 \mathrm{~min}$ at $4^{\circ} \mathrm{C}$. The fixed COCs were incubated in TUNEL reaction medium for $1 \mathrm{~h}$ at $38.5^{\circ} \mathrm{C}$, then washed and mounted on slides. Whole-mount COCs were examined under an epifluorescence microscope (Olympus, Tokyo, Japan) following TUNEL assay and DAPI staining, and the number of apoptotic nuclei and total number of nuclei were counted.

\section{Statistical analysis}

All percentage data obtained in this study are presented as the mean \pm standard deviation (SD). Moreover, Western blot experiments were performed in triplicate and all values were presented as the mean \pm standard error of the mean (SEM). The results were analyzed using either a one-way ANOVA followed by Bonferroni's Multiple Comparison Test or by performing a $t$-test. All data were analyzed using the GraphPad Prism 5.0 software package (San Diego, CA, USA). Differences were considered significant at $* p<0.05, * *<0.01$, and $* * *<0.001$. 


\section{RESULTS}

\section{Changes in meiotic maturation and cumulus cells expansion in porcine COCs according to GM3 $(10 \mu \mathrm{M})$ treatment time during IVM periods.}

We investigated the meiotic maturation and cumulus cells expansion according to GM3 treatment time (Con; non-treated, only IVM I treated; 0 - $22 \mathrm{~h}$, only IVM II treated; $22-44 \mathrm{~h}$, IVM I \& IVM II treated; 0 - 44 h) during porcine oocytes maturation. First, we confirmed that the meiotic maturation rate until metaphase II (M II) stage oocytes decreased significantly in the GM3-treated group for only IVM I periods (only IVM I treated group; $78.5 \pm 1.6 \%$ vs Con; $89.8 \pm 5.6 \% ; p<0.05$ ). Especially, the rate of germinal vesicle break-down stage (GVBD) oocytes significantly increased in the IVM I treated group (10.9 $\pm 5.5 \%$ ) compared to that in the other groups (Table 2; Con: $0.8 \pm 1.8 \%$ and IVM II: $2.8 \pm 2.9 \% ; p<0.05$ ). In addition, the rate of polar body extrusion decreased significantly $(p<$ 0.01 ) in the oocytes treated with GM3 for IVM I period (Figure 2A). Next, we confirmed that cumulus cells expansion and expressions of cumulus cells expansion factors (HAS2, TNFAIP6, and $P T X 3)$ were significantly decreased $(p<0.001)$ in the IVM I treated group compared to that in the control group (Figure 2B, C). In case of GM3 treatment for 0 - $44 \mathrm{~h}$ IVM, as expected, meiotic maturation, GV arrest, polar body formation, cumulus cell expansion, and oocyte maturation rate were higher than the other treated groups. These results demonstrated that ganglioside GM3 interfered with the porcine oocytes maturation and cumulus cells expansion at the time of early maturation.
Protein levels of ST3GAL5 and EGFR-ERK1/2 signaling in porcine COCs according to GM3 treatment time

To confirm the effects of exogenous ganglioside GM3 on EGFR-mediated ERK1/2 signaling in porcine COCs maturation, we investigated the protein expression of ST3GAL5, EGFR, p-ERGR, ERK1/2, and p-ERK1/2 in porcine COCs, according to GM3 treatment time. As shown in Figure 3, we confirmed that treatment with exogenous ganglioside GM3 during $22 \mathrm{~h}$ IVM decreased the expression of ST3GAL5 and EGFR downstream factors (EGFR and ERK1/2) protein levels in porcine COCs at $44 \mathrm{~h}$ of IVM. In particular, the expression of EGFR, p-EGFR, and $\mathrm{p}$-ERK1/2 protein levels appeared lowest in matured COCs derived from IVM I $(0-22 \mathrm{~h})$ group $(p<0.001$; compared to control group). Our results demonstrated that ganglioside GM3 inhibits the EGFR-derived ERK1/2 signaling pathway, regardless of treatment time. The expression of EGFR-mediated ERK1/2 signaling proteins in porcine COCs decreased in ganglioside GM3-treated groups during IVM I.

\section{Changes of cellular apoptosis in porcine COCs according to GM3 treatment timing}

To confirm the cellular apoptosis by exogenous GM3 treatment on porcine oocyte maturation, we performed the TUNEL assay and western blotting analysis for protein level of Cleaved caspase 3 . As a result, the rate of positive apoptotic cells was significantly increased $(p<0.01)$ in the $22 \mathrm{~h} \mathrm{GM} 3$ treatment group compared to that in the control group (Figure 4A). As shown in Figure 4B, we confirmed that treatment of exogenous ganglioside GM3 during $22 \mathrm{~h}$ IVM significantly increased $(p<0.05)$ the expression of Cleaved caspase 3 protein level in porcine COCs at $44 \mathrm{~h}$. These

Table 2. Effects of exogenous GM3 according to treatment periods on meiotic maturation of porcine COCs

\begin{tabular}{|c|c|c|c|c|c|}
\hline \multirow{2}{*}{$\begin{array}{c}\text { GM3 treatment }(10 \mu \mathrm{M}) \\
\text { periods }\end{array}$} & \multirow{2}{*}{$\begin{array}{c}\text { No. of oocytes } \\
\text { examined }\end{array}$} & \multicolumn{4}{|c|}{$\%$ of oocytes (n) } \\
\hline & & GV & GVBD & M I & M II \\
\hline Non-treated & 156 & - & $0.8 \pm 1.8(1)^{\mathrm{a}}$ & $9.4 \pm 6.8(14)^{\mathrm{a}}$ & $89.8 \pm 5.6(141)^{\mathrm{a}}$ \\
\hline $0-22 \mathrm{~h}$ & 140 & $1.4 \pm 1.9(2)$ & $10.9 \pm 5.5(15)^{b}$ & $9.3 \pm 3.2(13)^{\mathrm{a}}$ & $78.5 \pm 1.6(110)^{b}$ \\
\hline $22-44 \mathrm{~h}$ & 158 & $3.9 \pm 2.9(6)$ & $2.8 \pm 2.9(4)^{\mathrm{a}}$ & $9.8 \pm 3.8(15)^{\mathrm{a}}$ & $83.6 \pm 4.6(133)^{b}$ \\
\hline $0-44 \mathrm{~h}$ & 143 & $2.1 \pm 2.0$ & $7.4 \pm 3.4(10)^{b}$ & $19.6 \pm 2.5(28)^{\mathrm{d}}$ & $70.9 \pm 5.3(102)^{\mathrm{c}}$ \\
\hline
\end{tabular}

This experiment was replicated three times. Data are the mean \pm SD. Different superscripts denote a significant difference compared with other groups $(p<0.05)$ 
(A)
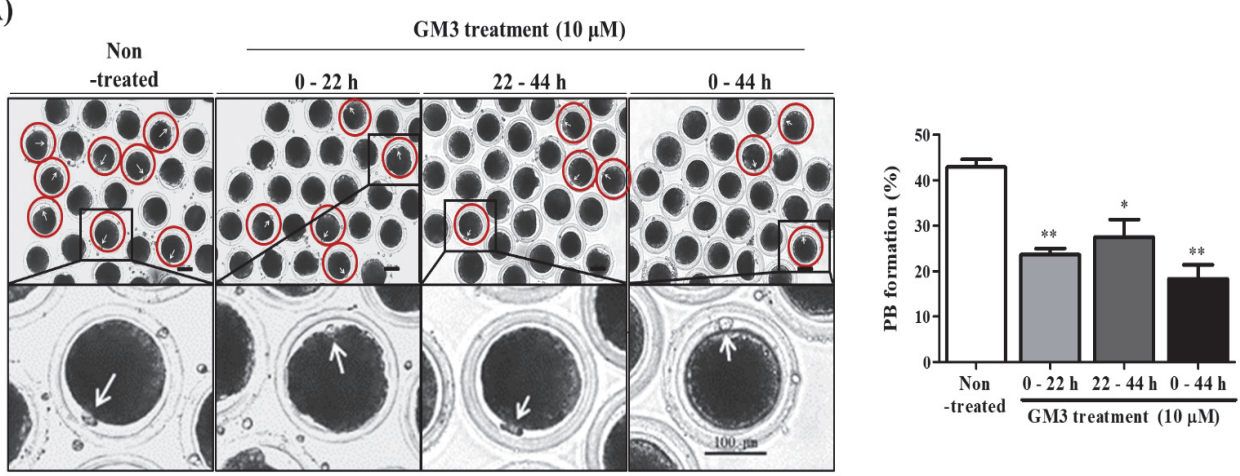

(B)
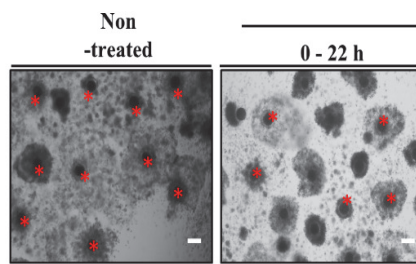

GM3 treatment $(10 \mu \mathrm{M})$
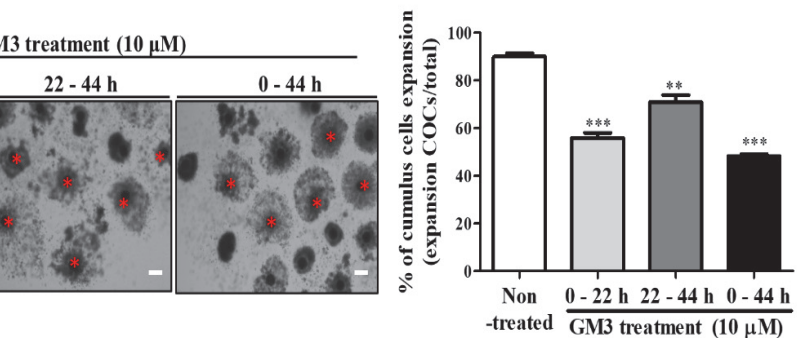

(C)
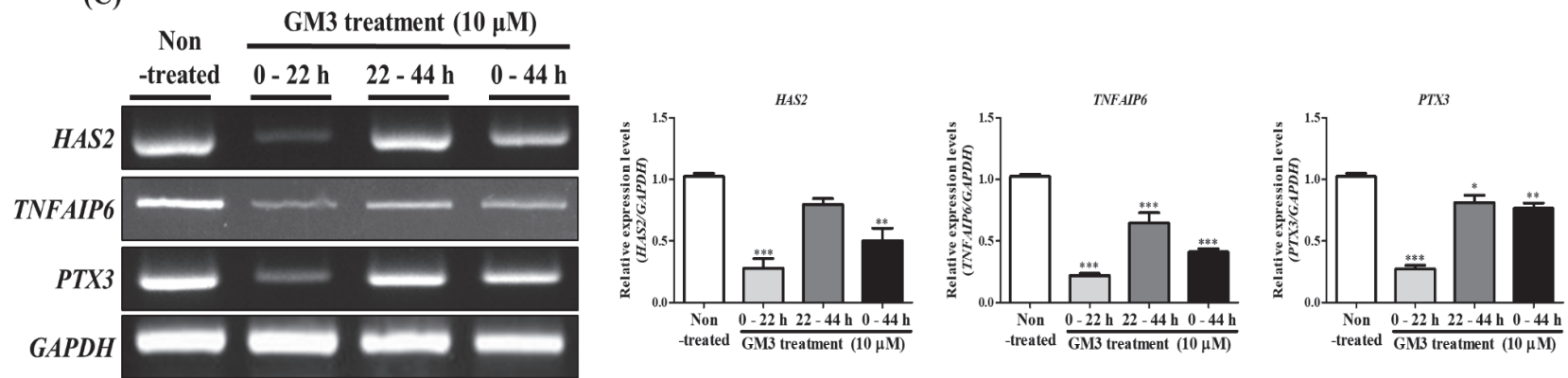

Figure 2. Effects of exogenous ganglioside GM3 on oocytes maturation and cumulus cell expansion in porcine COCs during $22 \mathrm{~h}$ and/or $44 \mathrm{~h}$ of IVM. (A) Polar body extrusion and (B) morphological of cumulus cells expansion in maturated COCs according to different GM3 treatment periods. Scale bars $=100 \mu \mathrm{m}$. Red asterisk is expanded COCs. (C) Expression of HAS2, TNFAIP6 and PTX3 in COCs cultured with GM3 treatment periods at IVM II. These mRNA levels were normalized to GAPDH expression as a control. Data in the bar graph represent the mean \pm SEM of three independent experiments. Differences in non-treated group compared with other groups were considered significant at $* p<0.05$, **<0.01, and $* * *<0.001$.

results demonstrated that treatment of exogenous ganglioside GM3 during early maturation periods induced apoptosis of porcine COCs.

\section{DISCUSSION}

In the present study, we first demonstrated the detailed effects of exogenous ganglioside GM3 on meiotic maturation, GV arrest, polar body formation, and cumulus cells expansion, according to the GM3 treatment periods (non-treated, IVM I, IVM II, and IVM I \& IVM II) during porcine oocyte IVM. Our results showed that porcine oocyte maturation was reduced by increasing GV stage arrest at $44 \mathrm{~h}$ IVM after $10 \mu \mathrm{M}$ GM3 treatment. In addition, the protein levels of EGFR, p-EGFR, ERK1/2, and p-ERK1/2 decreased in the GM3-treated group for IVM I only compared to the control group. Under GM3 treatment for $22 \mathrm{~h}$ of IVM, cellular apoptosis and apoptotic protein level (Cleaved caspase 3) in the matured COCs increased compared to the non-treated control. The meiotic maturation, cumulus cell expansion, and polar body formation in porcine COCs in the GM3-treated group for $22 \mathrm{~h}$ IVM decreased by reduction of the EGFR-derived ERK1/2 signal activity.

Gangliosides are found in the plasma membranes of mammalian cells and are particularly abundant in the neurons (Mirkin, et al. 
(A)

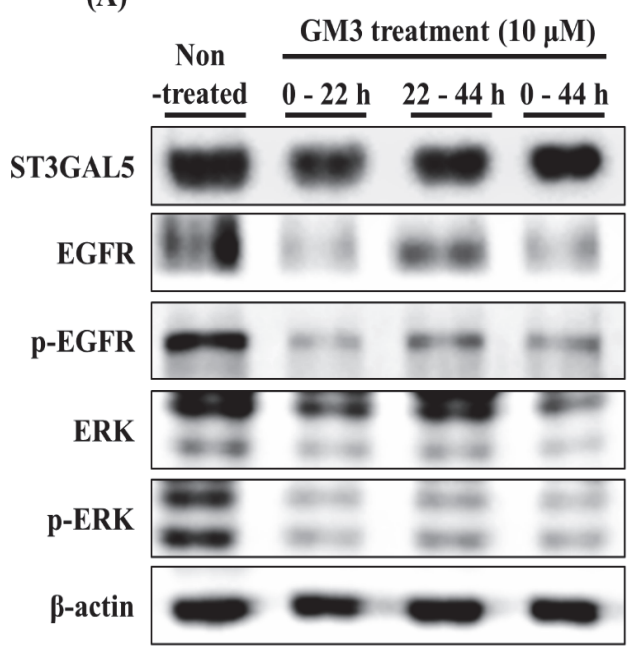

(B)
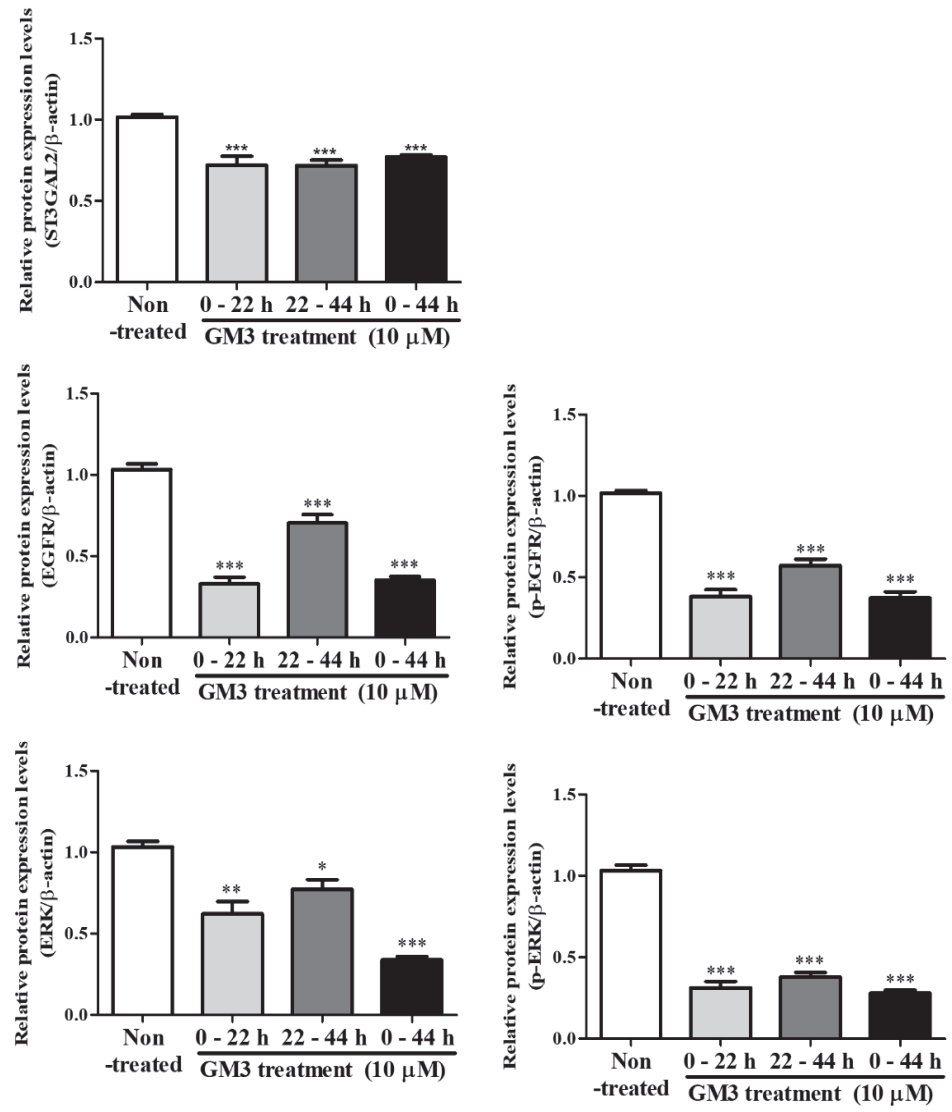

Figure 3. Western blot analysis of ST3GAL5 and EGFR-derived ERK1/2 signaling in maturated porcine COCs at $22 \mathrm{~h}$ and/or $44 \mathrm{~h}$ of IVM after GM3 $10 \mu \mathrm{M}$ treatment. (A) Western blot analysis of the EGFR-derived ERK1/2 signaling (EGFR, p-EGFR, ERK1/2 and p-ERK1/2) factors in maturated COCs after GM3 $10 \mu \mathrm{M}$ treatment at $22 \mathrm{~h}$ and/or $44 \mathrm{~h}$ of IVM. The protein levels were normalized to that of $\beta$-actin as a control. (B) Histogram values of densitometry analysis were obtained using ImageJ software. Bar graph data represent the least-squares means \pm SEM of three independent experiments. $(* p<0.05, * * p<0.01$, and $* * * p<0.001$ compared to non-treated group as control)

2002). Gangliosides are found at each embryonic developmental stage of mice, including follicular development, spermatogenesis, and embryogenesis. Ganglioside GM3 is expressed in primary follicles and Graafian follicles during the follicular growth in mouse ovaries (Kwak, et al. 2011). In diabetic mice, ganglioside GM3 decreased during preimplantation embryo development (Kwak, et al. 2003). A recent study reported that ganglioside GD1a improved oocytes maturation and preimplantation embryos development in porcine (Kim, et al. 2016). In contrast, ganglioside GM3 reduced meiotic maturation and cumulus cells expansion during porcine COCs maturation (Chae, et al. 2015; Park, et al. 2017). To confirm the effect of ganglioside GM3 on porcine oocytes maturation, we examined the ganglioside GM3 divided into four treatment periods groups. To confirm the changes in GM3 expression pattern, we also investigated the protein levels of ST3GAL5, a specific GM3-synthesizing enzyme, in matured porcine COCs. As a result, the expression of ST3GAL5 was decreased regardless of ganglioside GM3 treatment time in porcine COCs (Figure 4). According to our previous study, the exogenous GM3 exposure for $44 \mathrm{~h}$ IVM in porcine oocyte induced apoptosis by reduction of cell proliferation signaling (Chae, et al. 2015). As shown in Figure 2 and Table 1, meiotic maturation, cumulus cells expansion, and mRNA levels of cumulus cells expansion factors (HAS2, TNFAIP6, and PTX3) in porcine COCs of the ganglioside GM3-treated group for IVM I $(0-22 \mathrm{~h})$ were significantly decreased. These results showed the negative effects of $10 \mu \mathrm{M}$ GM3 treatment for $22 \mathrm{~h}$ IVM, which causes damage similar to GM3 treatment for $44 \mathrm{~h}$ IVM, and reduces the meiotic maturation rate, cumulus expansion, and polar body formation of porcine COCs. Based on these results, we determined that ganglioside GM3 during the IVM I (22 h) period was involved in GV arrest via inhibition of EGFR-derived ERK1/2 signal on meiotic maturation and cumulus cells expansion in porcine COCs. 
(A)
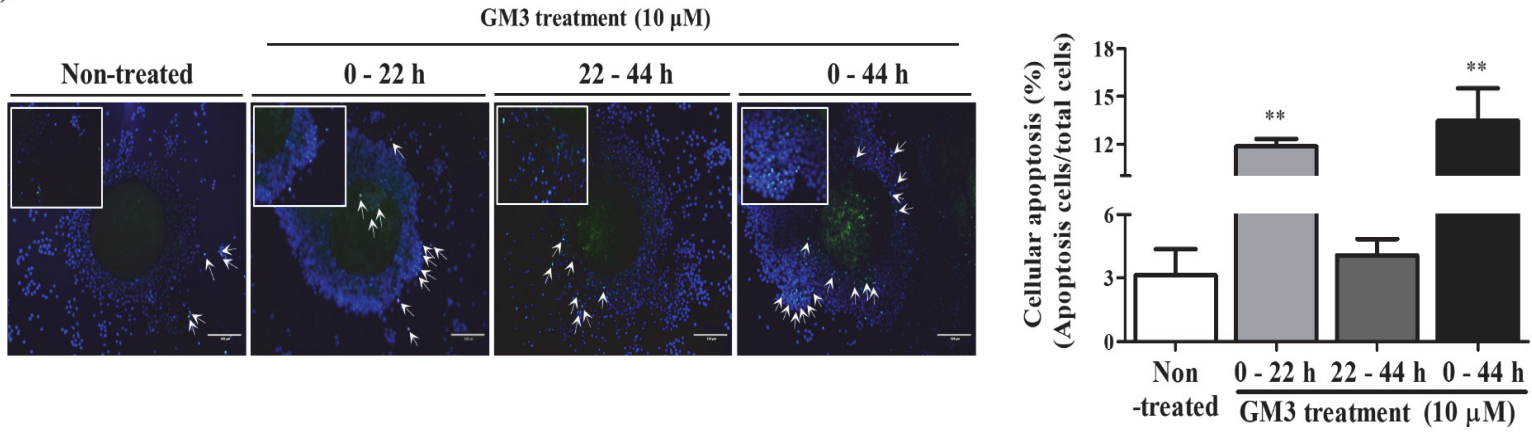

(B)
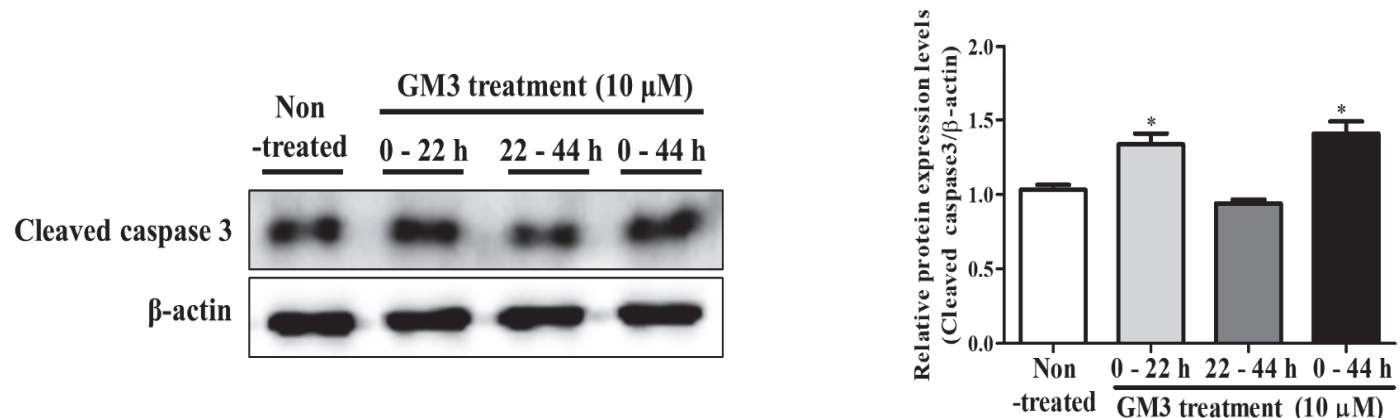

Figure 4. Changes in cellular apoptosis and apoptotic factor expression in maturated COCs according to different GM3 treatment periods. (A) Representative TUNEL assay images and (B) western blots analysis of apoptosis factors (Cleaved caspase 3 ) in maturated COCs according to different GM3 treatment periods. Scale bars $=100 \mu \mathrm{m}$. White arrow is apoptotic cells. The protein levels were normalized to that of $\beta$-actin as a control. Data in the bar graph represent the mean \pm SEM of three independent experiments. Differences in non-treated group compared with other groups were considered significant at $* p<0.05, * *<0.01$, and $* * *<0.001$.

Activation of EGFR is important for the maturation of porcine COCs (Meinecke and Krischek 2003; Prochazka and Blaha 2015; $\mathrm{Su}$, et al. 2003). In a previous study, ganglioside GM3 was found to inhibit the activation of EGFR in various cells (Julien, et al. 2013). The addition of GM3 to the culture medium inhibited the phosphorylation of EGFR in human epidermoid carcinoma cell line A431 (Bremer, et al. 1986). In human neuroblastoma cells, inhibition of EGFR phosphorylation and cell proliferation by GM3 treatment was reported (Mirkin, et al. 2002). Therefore, we investigated the relationship between EGFR signaling and ganglioside GM3 treatment periods in porcine COCs. Similar to the previous study, expressions of EGFR, p-EGFR, ERK1/2, and $\mathrm{p}$-ERK $1 / 2$ proteins were significantly decreased $(p<0.001)$ in the GM3-treated group during IVM I period compared to the control group (Figure 3). These results suggest that GM3 treatment during IVM I showed reversible effects on porcine oocyte maturation by reduction of EGFR-related signaling molecules.

During IVM of porcine COCs, cumulus cells contribute to the meiotic maturation of oocytes through the transfer of nutrients and signaling transduction (Liu, et al. 2015). According to previous studies, acrylamide reduced oocytes maturation via increasing of apoptotic cells in mouse COCs (Liu, et al. 2015), whereas, BMP15 reduced apoptotic cells in cumulus cells (Zhai, et al. 2013). A previous study also reported that ganglioside GM3 induced apoptosis and DNA damage during mouse oocytes maturation (Kwak, et al. 2003; Park, et al. 2017). Therefore, apoptosis is an important indicator used in the evaluation of COCs quality. As shown in Figure 4, the percentages of apoptotic cells and Cleaved caspase 3 were significantly increased in the ganglioside GM3 treatment group during IVM I period. Our result suggests that ganglioside GM3 induces apoptosis during IVM of porcine COCs.

In conclusion, we demonstrated that ganglioside GM3 inhibits oocyte maturation and cumulus cell expansion by reducing EGFR activity and inducing apoptosis (Graphical summary Figure 5). Especially, ganglioside GM3 treatment during the IVM I period 


\section{Graphical summary}

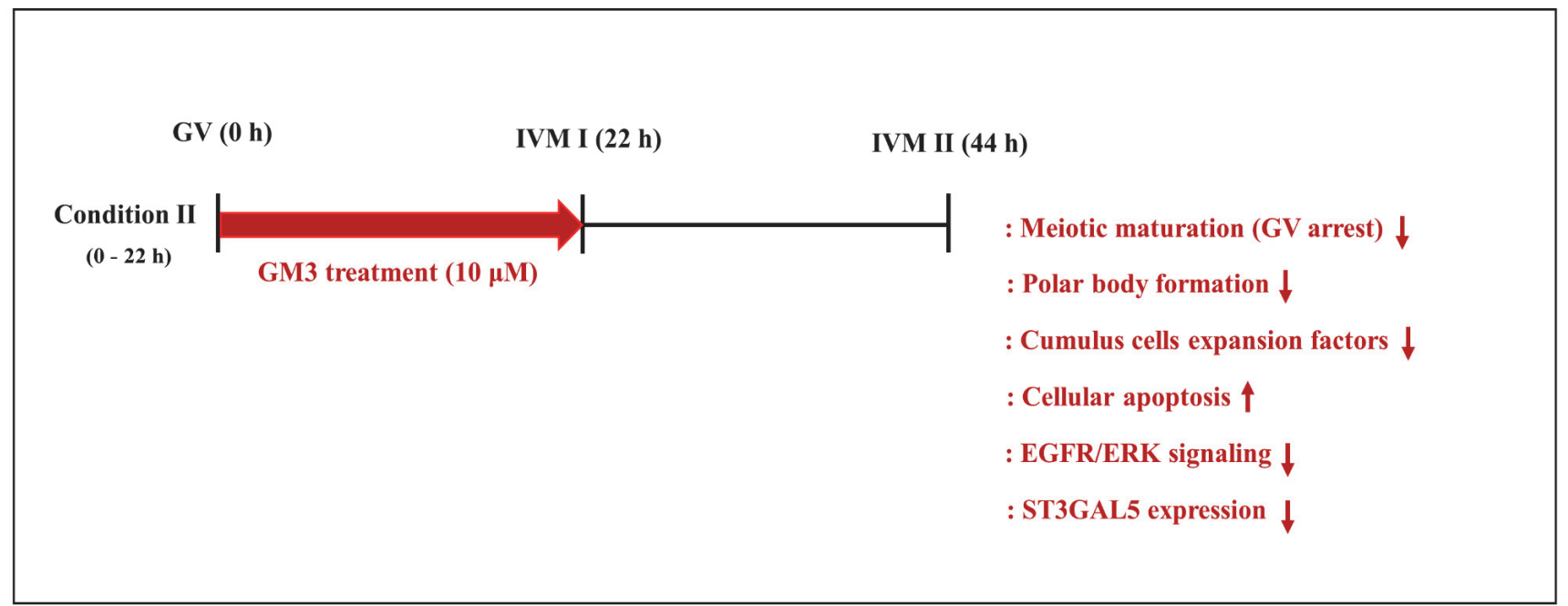

Figure 5. Graphical summary; exogenous ganglioside GM3 treatment during IVM I ( $0-22 \mathrm{~h})$ induced the decreasing meiotic maturation, polar body formation and cumulus cells expansion factors through the reduction of EGFR-related ERK1/2 activity and increasing of cellular apoptosis in porcine oocyte.

significantly inhibited meiotic maturation, cumulus cells expansion and EGFR-related signaling pathway. Also, ganglioside GM3 significantly increased apoptotic cell numbers and expression of apoptotic factor in porcine COCs. Therefore, the role of ganglioside GM3 in porcine oocyte maturation may be confirmed by the inhibition of ganglioside GM3.

\section{ACKNOWLEDGMENT}

This research was supported by a Daegu University Research Grant, 2016.

\section{REFERENCES}

Bremer EG, Schlessinger J and Hakomori S. 1986. Gangliosidemediated modulation of cell growth. Specific effects of GM3 on tyrosine phosphorylation of the epidermal growth factor receptor. J Biol Chem, 261:2434-2440.

Chae SK, Park HJ, Kim JW, Ahn JH, Park SY, Park JY, Yang SG and Koo DB. 2015. Changes of ganglioside GM3 expression in porcine oocyte maturation and early embryonic development in vitro. $J$ Embryo Transfer, 30:319-325.

De La Fuente R, O'Brien MJ and Eppig JJ. 1999. Epidermal growth factor enhances preimplantation developmental competence of maturing mouse oocytes. Hum Reprod, 14:3060-3068.

Goud PT, Goud AP, Qian C, Laverge H, Van der Elst J, De Sutter P and Dhont M. 1998. In-vitro maturation of human germinal vesicle stage oocytes: role of cumulus cells and epidermal growth factor in the culture medium. Hum Reprod, 13:1638-1644.

Huang X, Li Y, Zhang J, Xu Y, Tian Y and Ma K. 2013. Ganglioside GM3 inhibits hepatoma cell motility via downregulating activity of EGFR and PI3K/AKT signaling pathway. J Cell Biochem, 114:1616-1624.

Illera MJ, Lorenzo PL, Illera JC and Petters RM. 1998. Developmental competence of immature pig oocytes under the influence of EGF, IGF-I, follicular fluid and gonadotropins during IVM-IVF processes. Int J Dev Biol, 42:1169-1172.

Ju EJ, Kwak DH, Lee DH, Kim SM, Kim JS, Kim SM, Choi HG, Jung KY, Lee SU, Do SI, Park YI and Choo YK. 2005. Pathophysiological implication of ganglioside GM3 in early mouse embryonic development through apoptosis. Arch Pharm Res, 28:1057-1064.

Julien S, Bobowski M, Steenackers A, Le Bourhis X and Delannoy P. 2013. How Do Gangliosides Regulate RTKs Signaling? Cells, 2:751-767.

Kim JW, Park HJ, Chae SK, Ahn JH, Do GY, Choo YK, Park JJ, Jung BD, Kim SU, Chang KT and Koo DB. 2016. Ganglioside GD1a promotes oocyte maturation, furthers preimplantation development, and increases blastocyst quality in pigs. $J$ Reprod 
Dev, 62:249-255.

Kwak DH, Jung KY, Lee YC and Choo YK. 2003. Expressional changes of ganglioside GM3 during ovarian maturation and early embryonic development in $\mathrm{db} / \mathrm{db}$ mice. Dev Growth Differ, 45:95-102.

Kwak DH, Seo BB, Chang KT and Choo YK. 2011. Roles of gangliosides in mouse embryogenesis and embryonic stem cell differentiation. Exp Mol Med, 43:379-388.

Li Y, Huang X, Wang C, Li Y, Luan M and Ma K. 2015. Ganglioside GM3 exerts opposite effects on motility via epidermal growth factor receptor and hepatocyte growth factor receptor-mediated migration signaling. Mol Med Rep, 11:2959-2966.

Liu S, Jiang L, Zhong T, Kong S, Zheng R, Kong F, Zhang C, Zhang L and An L. 2015. Effect of Acrylamide on Oocyte Nuclear Maturation and Cumulus Cells Apoptosis in Mouse In Vitro. PLoS One, 10:e0135818.

Meinecke B and Krischek C. 2003. MAPK/ERK kinase (MEK) signalling is required for resumption of meiosis in cultured cumulus-enclosed pig oocytes. Zygote, 11:7-16.

Mirkin BL, Clark SH and Zhang C. 2002. Inhibition of human neuroblastoma cell proliferation and EGF receptor phosphorylation by gangliosides GM1, GM3, GD1A and GT1B. Cell Prolif, 35:105-115.

Mlynarcikova A, Nagyova E, Fickova M and Scsukova S. 2009. Effects of selected endocrine disruptors on meiotic maturation, cumulus expansion, synthesis of hyaluronan and progesterone by porcine oocyte-cumulus complexes. Toxicol In Vitro, 23:371-377.

Park HJ, Chae SK, Kim JW, Yang SG, Jung JM, Kim MJ, Wee G, Lee DS, Kim SU and Koo DB. 2017. Ganglioside GM3 induces cumulus cell apoptosis through inhibition of epidermal growth factor receptor-mediated PI3K/AKT signaling pathways during in vitro maturation of pig oocytes. Mol Reprod Dev, 84:702-711.

Prochazka R and Blaha M. 2015. Regulation of mitogenactivated protein kinase $3 / 1$ activity during meiosis resumption in mammals. J Reprod Dev, 61:495-502.

Rieger D, Luciano AM, Modina S, Pocar P, Lauria A and Gandolfi F. 1998. The effects of epidermal growth factor and insulin-like growth factor I on the metabolic activity, nuclear maturation and subsequent development of cattle oocytes in vitro. J Reprod Fertil, 112:123-130.

Sen A and Caiazza F. 2013. Oocyte maturation: a story of arrest and release. Front Biosci (Schol Ed), 5:451-477.

Su YQ, Denegre JM, Wigglesworth K, Pendola FL, O'Brien MJ and Eppig JJ. 2003. Oocyte-dependent activation of mitogenactivated protein kinase (ERK1/2) in cumulus cells is required for the maturation of the mouse oocyte-cumulus cell complex. Dev Biol, 263:126-138.

Wang XQ, Sun P and Paller AS. 2003. Ganglioside GM3 blocks the activation of epidermal growth factor receptor induced by integrin at specific tyrosine sites. J Biol Chem, 278:48770-48778.

Yoshikawa M, Go S, Suzuki S, Suzuki A, Katori Y, Morlet T, Gottlieb SM, Fujiwara M, Iwasaki K, Strauss KA and Inokuchi J. 2015. Ganglioside GM3 is essential for the structural integrity and function of cochlear hair cells. Hum Mol Genet, 24:2796-2807.

Zhai B, Liu H, Li X, Dai L, Gao Y, Li C, Zhang L, Ding Y, $\mathrm{Yu} \mathrm{X}$ and Zhang J. 2013. BMP15 prevents cumulus cell apoptosis through CCL2 and FBN1 in porcine ovaries. Cell Physiol Biochem, 32:264-278. 